\title{
Prof. Hilary Koprowski (1916-2013)
}

\begin{abstract}
W dniu 11 kwietnia 2013 roku zmarł w Filadelfii Profesor Hilary Koprowski, z wykształcenia lekarz, wybitny uczony, specjalista z zakresu wirusologii, immunologii i biologii raka, a ponadto utalentowany kompozytor i pianista, humanista, znawca i kolekcjoner malarstwa, głównie holenderskiego i włoskiego.

Urodził się 3 grudnia $1916 \mathrm{r}$. wWarszawie. Ojciec był przedsiębiorcą, matka Sonia z domu Berland - lekarzem dentystą. Równolegle z nauką w Gimnazjum im. M. Reja Hilary uczęszczał do

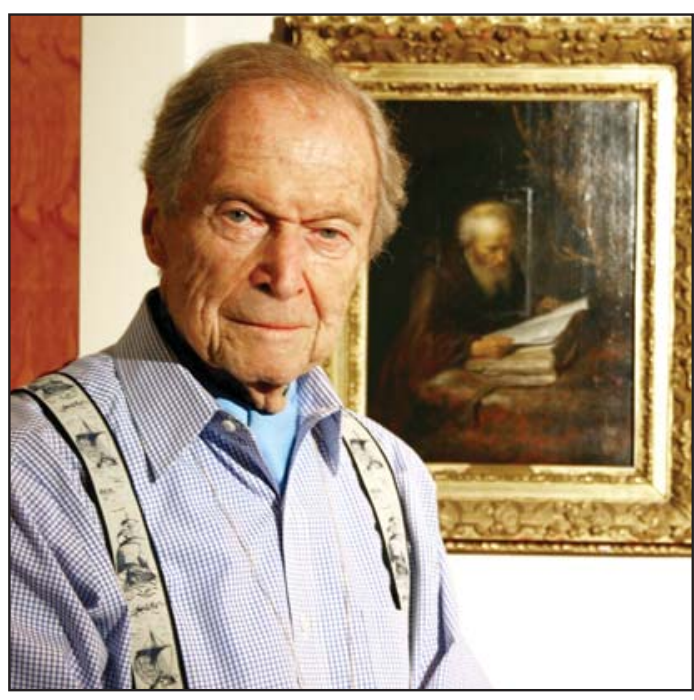

Prof. Hilary Koprowski w swojej galerii malarstwa
\end{abstract}

rażenia mięśni klatki piersiowej. Badania zakończyły się sukcesem: po raz pierwszy Koprowski uzyskał szczepionkę, stosując osłabioną (atenuowaną) postać wirusa. Szczepionka mogła być podawana doustnie, co znacznie ułatwiało walkę z epidemią polio i co wyróżniało ją od szczepionek opracowanych przez Salka i Sabina.

W Polsce w latach 50. panowała epidemia polio, corocznie chorowało kilka tysięcy dzieci (w 1958 r. prawie 6 tysięcy). Szczepionką Koprowskiego uratowa-
Konserwatorium, gdzie opanował sztukę gry i kompozycji na fortepianie. W 1939 r. ukończył studia medyczne na Uniwersytecie Warszawskim. Podczas ostatnich trzech lat studiów był też asystentem w Zakładzie Doświadczalnej Patologii. W czasie studiów ożenił się z koleżanką Ireną Grasberg. W 1939 r. wraz z żoną przeniósł się do Rzymu, gdzie przez rok uczęszczał do Santa Cecilia Conservatory. W polskiej ambasadzie w Rzymie jako lekarz brał udział w kwalifikowaniu i naborze żołnierzy do polskiej armii tworzącej się we Francji. Żona w tym czasie przebywała we Francji.

W 1940 roku Koprowscy wraz z urodzonym we Francji synkiem (Claude) przez Hiszpanię i Portugalię wyemigrowali do Brazylii. W Rio de Janeiro, w Yellow Fever Research Service Fundacji Rockefellera przez cztery lata Koprowski pracował nad szczepionką przeciw żółtej febrze. W 1944 roku Koprowscy przenieśli się na stałe do Stanów Zjednoczonych.

Osiedlili się w Pearl River w stanie Nowy Jork. Tu, w Laboratorium Lederle (American Cyanamid Company), Hilary rozpoczął pracę nad szczepionką przeciw chorobie Heinego-Medina. Choroba ta, zwana w skrócie „polio” (od poliomyelitis), jest chorobą wirusową, dotyczy dzieci i młodzieży i ma dramatyczny przebieg: wirus niszczy komórki nerwowe i nerwy rdzenia kręgowego, doprowadzając do wiotkiego porażenia kończyn dolnych, a czasami do po- no przed ciężkim kalectwem miliony dzieci i młodzieży na całym świecie, w tym również w Polsce, bowiem Profesor ofiarował Polsce ok. 9 milionów dawek szczepionki — zostało zaszczepionych ok. 7300000 dzieci i epidemia została opanowana.

Z faktem daru Koprowskiego związany był przykry incydent, o którym niegdyś mi opowiadał. Profesor, już wówczas kolekcjoner malarstwa, zakupił w Polsce obraz przedwojennego malarza (bodajże Nowakowskiego) z przekonaniem, że Polska w geście drobnej wdzięczności zezwoli na jego wywiezienie. Władze odmówiły mu jednak wydania zezwolenia, a interwencja ministra zdrowia była nieskuteczna. Ten nieoczekiwany fakt wywołał pewien zawód i rozczarowanie postawą władz polskich.

W Laboratorium Lederle Koprowski pracował do roku 1957, przez ostatnie 9 lat jako zastępca dyrektora Section of Viral and Rickettsial Research. W 1957 r. objął funkcję dyrektora w The Wistar Institute of Anatomy and Biology w Filadelfii, gdzie pracował kolejne 35 lat. Z miejsca dokonał głębokich zmian: z instytucji niemal muzealnej, pozostającej niejako w letargu, wkrótce powstał ożywiony, nowoczesny, prestiżowy ośrodek badań biomedycznych. Kształciło się w nim i pracowało wielu naukowców ze świata, także z Polski. 
Problematyka, która interesowała Koprowskiego, mieściła się w obrębie wirusologii i immunologii oraz biologii raka. Wrazz dr. T. Wiktorem opracował nowy typ szczepionki przeciw wściekliźnie u ludzi i zwierząt. Umożliwiła ona wyeliminowanie wścieklizny u lisów we Francji i Belgii. Inna problematyka dotyczyła badań nad wrażliwością komórek jajowych na wirusy onkogenne czy opracowanie monoklonalnych przeciwciał przeciwko wirusowi wścieklizny, a także przeciw antygenom raka jelita grubego. Interesował się również procesami biologicznymi powstającymi w wyniku fuzji komórek somatycznych. W ostatnich dekadach życia Koprowskiego bardzo interesowała go możliwość produkcji biopreparatów w roślinach przy użyciu techniki inżynierii genetycznej. Przy użyciu tej technologii udało się wyprodukować w szpinaku i tytoniu przeciwciała przeciwko wirusowi wścieklizny, a także - w tytoniu — przeciwciała przeciwko antygenom raka jelita grubego. We współpracy z polskimi badaczami w Instytucie Chemii Bioorganicznej PAN w Poznaniu Koprowski rozpoczął badania nad uzyskaniem w sałacie przeciwciał przeciwko wirusowi zapalenia wątroby typu B. Był entuzjastą techniki modyfikacji genetycznej roślin i zwierząt dla potrzeb nauki, zwłaszcza biomedycyny, jednakże wykazywał przezorność i pewien dystans do wprowadzania tej techniki dla celów rolniczych.

Wracając do opracowanej przez Koprowskiego szczepionki przeciwko polio, należy wspomnieć o głośnym i trwającym wiele lat oskarżeniu Profesora o to, że jego doświadczenia i sposób produkcji szczepionki doprowadziły do uwolnienia z komórek małpich wirusa SIV (Simian Immnodeficiency Virus), który zanieczyścił doustną szczepionkę dla ludzi i rzekomo wywołał w Afryce pierwsze przypadki AIDS.

Oskarżenia te były bezpodstawne, chociaż rzeczywiście ludzki wirus HIV (Human Immunodeficiency Virus), obecny u chorych na AIDS, posiada wiele podobieństw do SIV, a produkcja szczepionki odbywała się z wykorzystaniem komórek małpich. W latach 50. nad szczepionką przeciwko polio pracowały liczne grupy badaczy. Wirus namnażany był zwykle na kulturach komórek nerkowych afrykańskiej małpy zielonej, pawiana lub makaka. Surowice do hodowli tych kultur uzyskiwano od odpowiednich gatunków naczelnych. Pierwsze szczepienia szczepionką Koprowskiego przeprowadzono w Afryce - w Burundi i Rwandzie — u ok. miliona dzieci. Ostatecznie do praktyki medycznej weszły cztery rodzaje szczepionki (Sabina, Salka, Coxa i Koprowskiego), ale tylko szczepionka Alberta Sabina (nb. również naszego żydowskiego współobywatela urodzonego w Łodzi) uzyskała licencję na stosowanie w USA jako specyfik dający najmniej efektów ubocznych.

Na podstawie niepełnego rozeznania źródeł tych kultur i surowic oraz wadliwych ocen epidemiologicznych i historii epidemii AIDS, dziennikarz T. Curtis opublikował w 1992 r. w czasopiśmie Rolling Stone artykuł głoszący hipotezę, że szczepionka Koprowskiego została zakontaminowana wi-

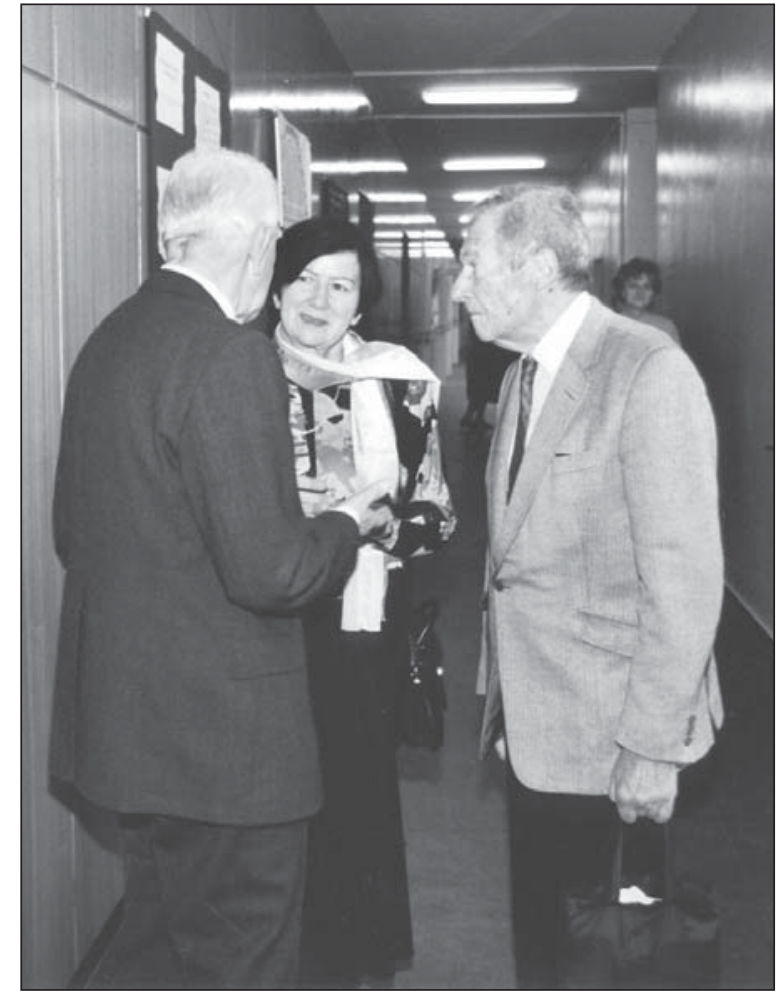

Wizyta w Gliwicach, 1995. Od lewej, prof. Kazimierz Dux, Kasia Chorąży, prof. Hilary Koprowski

rusem SIV, mającym cechy wspólne z wirusem HIV, co spowodowało wybuch epidemii AIDS w Afryce, a następnie na innych kontynentach. Koprowski został zatem oskarżony o wygenerowanie czynnika zakaźnego groźnej choroby. Mimo jego rzeczowych wyjaśnień, opublikowanych w liście do Science, i korzystnego wyroku sądowego (z pozwu Koprowskiego przeciwko redakcji Rolling Stone i Curtisowi) sprawa nie wygasła. W 7 lat później dziennikarz brytyjski E. Hooper opublikował książkę The River:A Journey to the Source of HIV and AIDS, gdzie ponownie podniósł sprawę związku AIDS ze szczepionką Koprowskiego. Zarzuty przybrały jeszcze inną formę w postaci francuskiego filmu "Czy świat oszalał? Skąd wzięło się AIDS?". Koprowski ponownie odparł je, przytaczając fakty doświadczalne i epidemiologiczne: kultury komórkowe nerki pochodziły nie od szympansa (nosiciela SIV), lecz od makaka, a kilka badań niezależnych ekspertów nie stwierdziło w szczepionce Koprowskiego ani wirusa SIV, ani HIV. Ponadto epidemia AIDS w Afryce wybuchła znacznie wcześniej, niż zaczęto doświadczenia nad szczepionką polio. Podobne zarzuty opublikowała jedna z gazet w Polsce, a autor niniejszego wspomnienia polemizował z nimi. Należy jednak pamiętać, że wyjaśnienie pochodzenia AIDS jest niezwykle złożone, a możliwość przeniesienia chorób wirusowych od zwierząt na ludzi jest faktem.

Po odejściu z Instytutu Wistara Koprowski otrzymał pozycję profesora w Zakładzie Mikrobiologii i Immunologii wThomas Jefferson University (Filadelfia) i pozycję dyrektora 
Centrum Neurowirusologii i Laboratoriów Fundacji Biotechnologii w tymże Uniwersytecie.

Praktycznie do końca swojej aktywności był związany z tym ośrodkiem. Pracował nad wirusami i żył muzyką. Jego dorobek naukowy jest olbrzymi i wynosi ponad 900 publikacji.

Oprócz działalności badawczej pełnił wiele funkcji w agendach państwowych, organizacjach i towarzystwach naukowych. Był konsultantem WHO w Genewie, członkiem National Research Council, członkiem, kilku sekcji i komisji Narodowych Instytutów Zdrowia w Bethesda, członkiem a następnie przewodniczącym Komisji Doradców Naukowych w Narodowym Instytucie Raka (NCl) w Betesda i wielu innych placówkach.

Jedenaście uniwersytetów nadało Mu doktoraty honorowe lub równorzędne wyróżnienia, w tej liczbie cztery uczelnie polskie - Akademia Medyczna w Poznaniu, Lublinie i Warszawie oraz SGGW. Był członkiem Amerykańskiej Narodowej Akademii Nauk, Amerykańskiej Akademii Sztuki i Nauk, Nowojorskiej Akademii Nauk i in., jak również członkiem zagranicznym Polskiej Akademii Nauk i Polskiej Akademii Umiejętności, Rosyjskiej Akademii Nauk Medycznych, Fińskiej Akademii Nauk i Literatury i Królewskiego Towarzystwa Medycyny w Wielkiej Brytanii. Był też wyróżniony Nagrodą Miasta Filadelfii, Milenijną Nagrodą Fundacji Alfreda Jurzykowskiego, Medalem Kopernika PAN, Nagrodą Fundacji Kościuszkowskiej oraz innymi.

Liczne państwa przyznały Mu najwyższe odznaczenia. Król Belgii odznaczył Go Orderem Lwa, Francja przyznała Legię Honorową oraz Order Zasługi za Badania i Wynalazki, Finlandia - Komandorski Order Lwa Finlandii, San Marino - Order Medycyny. Polska przyznała Krzyż Komandorski z Gwiazdą oraz KrzyżWielki Orderu Odrodzenia Polski. Otrzymał też tytuł Honorowego Obywatela Warszawy, a również Honorowe Obywatelstwo Celestynowa, z którym był związany od dzieciństwa; dzieci polskie mianowały go Kawalerem Orderu Uśmiechu. Od kilku lat Dyrekcja naszego Instytutu funduje Nagrodę im. Hilarego Koprowskiego Polskiego Towarzystwa Onkologicznego dla młodych lekarzy i badaczy za wybitną pracę z dziedziny onkologii.

W tym miejscu wspomnę jeszcze o mało znanym „, wątku gliwickim", który łączył Koprowskiego z naszym ośrodkiem i trwał przez wiele lat. Moja pierwsza kilkudniowa wizyta w Instytucie Wistara na zaproszenie Profesora, połączona z wykładem, miała miejsce w 1962 r. Zamieszkałem w Instytucie, w przytulnym pokoju gościnnym, a właściwie małym apartamencie składającym się z pokoju sypialnego i pokoju dziennego z wnęką, gdzie można było przyrządzić sobie kawę lub herbatę, usmażyć jajecznicę lub skorzystać z różnych wiktuałów, łakoci i napojów trzymanych w opasłej lodówce, gdzie była także kolekcja różnych gatunków piwa. Do tego dochodziła kolekcja trunków (whisky, dżinu i wódki). Pozostało mi w pamięci to niezwykle ciepłe przyjęcie, uzupełnione jeszcze koncertem w Filharmonii i kilkoma wspólnymi obiadami.

W latach 60. z inicjatywy Koprowskiego brałem udział w dyskusji w siedzibie PAN w Warszawie (Hilary Koprowski, Ksawery Rowiński - przewodniczący Wydziału Nauk Medycznych PAN, Bolesław Skarżyński — biochemik z AM w Krakowie i Kazimierz Dux — kierownik, Zakładu Biologii Nowotworów w Instytucie Onkologii w Warszawie) nad rozwinięciem badań z zakresu wirusologii raka w Polsce. W wyniku dyskusji postanowiono aby w "moim” (byłem wówczas świeżo mianowanym kierownikiem) Zakładzie Biologii Nowotworów (ZBN) w Gliwickim Oddziale Instytutu Onkologii, zorganizować zawiązek przyszłego zakładu wirusów onkogennych. Koprowski zaoferował szkolenie naszych pracowników w zakresie wirusów rakowych w Instytucie Wistara. Istotnie, wkrótce z zespołu ZBN wyłonił się kilkuosobowy Zakład Wirusów Onkogennych. Jego kierownikiem został dr Zenon Stęplewski. Grupa ta badała syntezę i właściwości tzw. dużego antygenu T małpiego wirusa SV40 (w tym czasie sugerowano również możliwość kontaminacji szczepionek tym wirusem). Profesor Koprowski przyjął na szkolenie kilku pracowników, ale staż w Instytucie Wistara był tak atrakcyjny, że troje z nich pozostało na stałe w Ameryce, w tym dr Stęplewski (obecnie profesor), który do końca życia Koprowskiego był jego najbliższym współpracownikiem. Dwóch innych pracowników wyemigrowało na stałe do Szwajcarii i USA. Gliwicki Zakład Wirusów Onkogennych został po kilku latach rozwiązany.

W latach 70. Koprowski ekscytował się nowym pomysłem: w Instytucie Wistara chciał utworzyć polską grupę badawczą, opartą na 6-8 pracownikach naszego zespołu. Twierdził, że może załatwić legalnie emigrację takiej grupy do USA. Kilkakrotnie zachęcał też mnie do zrealizowania tego pomysłu.

Potem namawiał mnie usilnie do przeniesienia się do International Agency for Research on Cancer (IARC) w Lyonie i nawet bez mojej wiedzy przesłał list rekomendujący na ręce ówczesnego dyrektora IARC Johna Higginsona. Zostałem zaproszony do Lyonu na rozmowę, ale propozycje badawcze grupy $d r$. de Thé, choć kuszące, nie odpowiadały mi, a ponadto - jak można było porzucić swój kraj na wiele lat lub na zawsze? Po mojej odmowie Koprowski napisał mi list z wyrzutami, że nie skorzystałem z tak unikalnej szansy życiowej.

W latach 90. nosił się z zamiarem zorganizowania w Polsce nowoczesnego ośrodka informacji naukowej, ale ten cel również nie doczekał się realizacji.

W trudnym okresie powojennym Prof. Koprowski pomagał naszemu Zakładowi Biologii Nowotworów w różny sposób. Chyba pierwsi i przez parę lat jedyni w Polsce otrzymywaliśmy Current Contents — Life Sciences, niezwykle pomocne wówczas źródło informacji o publikacjach naukowych, wydawane przez jego młodszego przyjaciela Eugene Garfielda. To wówczas unikatowe wydawnictwo udostępnia- 
liśmy kilku ośrodkom w Polsce. Przez wiele lat prenumerował dla nas czasopisma naukowe (m.in. Proceedings of the National Academy of Sciences of the US, Science i Nature), dosyłał odczynniki, a w przypadkach awarii aparatury badawczej zakupywał części zamienne. Była to istotna pomoc, gdyż zakup odczynników lub części zamiennych drogą oficjalną był procesem bardzo skomplikowanym i często praca laboratoryjna musiała być przerwana na wiele miesięcy.

Z Koprowskim spotykałem się wielokrotnie w Europie i USA, a także w Gliwicach, gdzie gościł trzy razy. Później, przy okazji spotkań, sławił w świecie kuchnię Kasi (mojej żony), zwłaszcza jej czerwony barszcz. Był znanym smakoszem i ekspertem kulinarnym, koneserem win i napojów.

Umiał przyciągać ludzi, cieszył się dużym autorytetem, ale był wymagający. Miał cechy przywódcze. Szczerze pomagał innym, ale też znany był z uprzejmego zwrotu „Czy mógłbyś, proszę, zrobić mi małą przysługę?”. A taka przysługa najczęściej dotyczyła transportu przez ocean. Czy była to płaskorzeźba, czy pokaźna, oprawiona w ramy akwarela z Polski, perski dywan zakupiony w Turcji lub 350-kilogramowy ładunek burgundzkiego wina — nie robiło różnicy. Starszy syn Koprowskiego Christopher wspominał dewizę ojca odnośnie przenoszenia bagażu: let-anyone-else-but-me-carry-it, nieco ekscentryczną, ale uzasadnioną wcześniej przebytą operacją kręgosłupa.

Był zdeterminowany w swoich zamiarach i w swoje przedsięwzięcia angażował innych, ale nie było w tym chęci ich wykorzystywania, ponieważ zawsze traktował ich przyjaźnie i przychodził z pomocą. W 1996 roku, gdy FBI aresztowała Daniela Carletona Gajduska, Koprowski był głęboko poruszony i natychmiast razem z Bobem Gallo zadeklarowali wielką kaucję i poręczenie swoim majątkiem za uwolnienie noblisty.

Utkwiło mi w pamięci spotkanie w Kolonii (RFN), gdy oprowadzał mnie po katedrze, a przy grobowcu Rychezy Lotaryńskiej, królowej Polski, żony Mieszka II i matki Kazimierza Odnowiciela wygłosił wykład o koligacjach rodów panujących ówczesnej Europy. Jego wiedza historyczna była imponująca.

Koprowscy mieszkali w bogato i ze smakiem urządzonym domu w Wynnewood pod Filadelfią, mieszczącym chyba z 10 pokoi a także pawilony dla obszernej biblioteki i galerii malarstwa. Liczna służba i budzący respekt owczarek francuski Porthos czuwali nad porządkiem. Podziwiałem kolekcję obrazów i słuchałem kompozycji Hilarego na fortepian w jego wykonaniu. Czerpał z muzyki siłę i pogodę ducha. Był uroczy, pełen życia i nowych twórczych pomysłów nie tylko w obszarze nauki. Znał historię, literaturę i geografię wielu krajów świata, w czym pomocna mu była znajomość kilku języków europejskich. To był barwny, ciepły i przyjazny ludziom człowiek renesansu, rzadko spotykana indywidualność. Z charakteru miał w sobie coś z sarmackich cech: pozornie beztroski, z dyskretną fantazją, kordialny, lubiący dobrze zjeść i wypić, patriota, przywiązujący dużą wagę do międzyludzkich kontaktów i przyjaźni. Może trochę ekscentryczny. Był świetnym wykładowcą i gawędziarzem. W pracy - wymagający od siebie i od pracowników.

W 2006 roku, w czasie mojej wizyty w NCl w Bethesda (MD), Hilary zadzwonił i zaprosił do odwiedzenia jego posiadłości wiejskiej w Oxford nad zatoką Chesapeake. Spędziłem tam jeden uroczy dzień w wygodnie urządzonym domu i na spacerze wokół przydomowej zieleni i nad własnym wybrzeżem nadmorskim. Żyła jeszcze wtedy żona Profesora - Irena, lekarz cytolog. Z Hilarym rozmawiałem długo; poruszaliśmy różne wątki, od naukowych do gospodarczych i politycznych. Interesował się z zatroskaniem tym, co dzieje się w ośrodkach badawczych w Polsce. Jego przyjazny stosunek do innych ludzi, a do Polski w szczególności emanował przy każdej rozmowie. W tym czasie był już wyraźnie przygaszony, choć w oczach stale jeszcze pojawiały siężywe ogniki. To było moje ostatnie spotkanie z Hilarym na ziemi amerykańskiej. Potem wymienialiśmy jedynie kartki na Boże Narodzenie z krótkimi informacjami. Kartki świąteczne były pomysłu Hilarego i nie zawsze nawiązywały do wątków sakralnych. Ostatnia kartka z 2011 roku była już prawie nieczytelna. Czas zniszczył jego niespożytą siłę i precyzję ruchów piszącej ręki. Odszedł wybitny uczony, człowiek dużej klasy, ciepły i życzliwy dla ludzi, zawsze pamiętający o Polsce — kraju swego pochodzenia.

\section{Prof. dr hab. n. med. Mieczysław Chorąży}

Centrum Onkologii — Instytut im. Marii Skłodowskiej-Curie Oddział w Gliwicach

e-mail: chorazy@io.gliwice.pl 